\title{
PENGEMBANGAN KURIKULUM PESANTREN, MADRASAH DAN SEKOLAH
}

\author{
Ahmad Arifai \\ Sekolah Tinggi Ilmu Tarbiyah Raudhatul Ulum Sakatiga \\ Email: sugrhu@gmail.com
}

\begin{abstract}
Abstrak
Penelitian ini membahas tentang pengembangan kurikulum pesantren, madrasah dan sekolah. Dengan tujuan untuk mengetahui bagaimana pengembangan tersebut. Metode yang digunakan dalam penelitian ini adalah pendekatan kualitatif yang berfokus kepada studi kepustakaan (library reseach). Hasil penelitian membuktikan bahwa Pesantren dan Madrasah merupakan suatu lembaga pendidikan yang lebih menekankan pada pendidikan agama. Kurikulum PAI di Madrasah memiliki suatu hal yang lebih pokok yang memang diharapkan dan bukan hanya dalam target tujuan PAI tapi juga sebagai pendidikan yang lahir dari agama islam diharapkan dapat berkompetensi jasmani dan rohani, artinya berkompetensi dalam hal sikap, skill, pengetahuan secara afektif, kognitif, psikomotorik sesuai dengan ajaran agama islam dalam aspek jasmani. Dan dengan adanya kurikulum madrasah diharapkan menjadikan anak didik menjadi makhluk yang beriman dan bertaqwa kepada Allah serta senatiasa mau mengamalkan apa yang telah diajarkan di dalam madrasah
\end{abstract}

Kata Kunci: Pengembangan Kurikulum, Pesantren, Madrasah, Sekolah

\section{Pendahuluan}

Kurikulum memegang kedudukan kunci dalam pendidikan, sebab berkaitan dengan arah, isi dan proses pendidikan yang pada akhirnya menentukan macam dan kualifikasi lulusan suatu lembaga pendidikan. Dalam suatu lembaga pendidikan, salah satu tokoh yang memiliki peranan yang begitu penting dalam pengembangan kurikulum adalah guru. Guru merupakan ujung tombak keberhasilan pendidikan yang terlibat langsung dalam mengembangkan, memantau, dan melaksanakan kurikulum sehingga pembelajaran dapat berjalan lancar dan dapat mencapai tujuan yang diharapkan.

Meskipun ilmu pengetahuan mengalami perkembangan yang cukup pesat, tidak berarti menyurutkan peranan guru. Bahkan, hasil-hasil teknologi tersebut akan menambah beban tugas dan tanggung jawab guru. Oleh karenanya, guru sebagai pelaku utama pendidikan diwajibkan memenuhi kewajibannya sebagai pendidik professional, dan - tentu saja sebagai pengembang kurikulum.

\section{a). Pengembangan kurikulum Pesantren}

Dalam beberapa penelitian terhadap pesantren ditemukan bahwa pesantren mempunyai kewenangan tersendiri dalam menyusun dan mengembangan kuurikulumnya. Menurut penelitian Lukens-Bull dalam bukunya Abdullah Aly, secara umum kurikulum pesantren dapat dibedakan menjadi empat bentuk, yaitu; Pendidikan Agama, pengalaman dan pendidikan moral, sekolah dan pendidikan umum serta, ketrampilan dan kursus (Aly, 2011: 184). 


\section{Pengembangan Kurikulum Pesantren, Madrasah dan Sekolah}

\section{Ahmad Arifai}

Pertama, kurikulum berbentuk pendidikan Agama Islam. Di dalam dunia pesantren, kegiatan belajar pendidikan Agama Islam lazim disebut sebagai ngaji atau pengajian. Kegiatan ngaji dipesantren pada praktiknya dibedakan menjadi dua tingkatan. Pada tingkatan awal ngaji sangatlah sederhana, yaitu para santri belajar membaca teks-teks Arab, terutama sekali Al-Qur'an. Tingakatan ini dianggap sebagai usaha minimal dari pendidikan agama yang harus dikuasai oleh para santri. Tingkatan berikutnya adalah para santri memilih kitabkitab islam klassik dan mempelajarinya dibawah bimbingan kyai. Adapun kitab-kitab yang dijadikan bahan untuk ngaji meliputi bidang ilmu: fikih, aqidah atau tauhid, nahwu, sharaf, balaghah, hadits, tasawuf, akhlak, ibadah-ibadah seperti sholat doa, dan wirid. Dalam penelitian Martin Van Bruinessen, ada 900 kitab kuning dipesantren. Hampir 500 kitab-kitab tersebut ditulis oleh ulama asia tenggara dengan bahasa yang beragam; bahasa Arab, Melayu, Jawa, Sunda, Madura, Indonesia, dan Aceh.

Kitab kuning dalam dunia pesantren mempunyai posisi yang siginifikan selain dari kharisma kyai itu sendiri. Dan kitab kuning itu sendiri dijadikan referensi dan buku pegangan dalam tiap-tiap pesantren, dan kurikulum sebagai sistem pendidikan daam sebuah pesantren tersebut.

Kedua, kurikulum berbentuk pengalaman dan pendidikan moral. Kegiatan keagamaan yang paling terkenal di dunia pesantren adalah kesalehan dan komitmen para santri terhadap lima rukun Islam. Kegiatan-kegiatan tersebut diharapkan mampu menumbuhkan kesadaran para santri untuk mengamalkan nilai-nilai moral yang di ajarkan pada saat ngaji. Adapun nilai-nilai moral yang ditekankan dipesantren adalah persaudaraan Islam, keikhlasan, kesederhanaan dan kesaudaraan Islam.

Ketiga, kurikulum berbentuk sekolah dan pendidikan umum. Pesantren memberlakukan kurikulum sekolah mengacu kepada pendidikan nasional yang dikeluarkan Departemen Pendidikan Nasional, sedangkan kurikulum Madrasah mengacu kepada pendidikan Agama yang diberlakukan oleh Departemen Agama.

Keempat, kurikulum berbentuk ketrampilan dan kursus. Pesantren memberlakukan kurikulum yang berbentuk ketrampilan dan kursus secara terencana dan terpogram melalui kegiatan ekstrakulikuler. Adapun kursus yang popular dipesantren adalah bahasa inggris, computer, setir mobil, reparasi sepeda motor, dan lain sebagainya. Kurikulum seperti ini diberlakukan di pesantren karena mempunyai dua alasan, yaitu alasan politis dan promosi. Dari segi politis, pesantren yang memberikan pendidikan ketrampilan dan kursus kepada para santrinya berarti merespon seruan pemerintah untuk peningkatan kemampuan sumber daya manusia (SDM). Hal ini berarti hubungan antara pesantren dengan pemerintah cukup harmonis. Sementara itu dari segi promosi terjadi peningkatan jumlah santri yang memliki pesantren-pesantren modern dan terpadu, dengan alasan adanya pendidikan ketrampilan dan kursus di dalamnya.

Sedangkan M Ridwan Nastir memberikan gambaran mengenai tingkat keanekaragaman pranata sesuai dengan spektrum komponen serta pengembangan suatu pesantren. Yang diklasifikasikan menjadi lima bagian, yaitu;

a) Pondok pesantren salaf/klasik; yaitu pondok pesantren yang didalamnya terdapat sistem pendidikan salaf (weton, sorogan, bandongan) dan sistem klasikal (madrasah) salaf.

b) Pondok pesantren semi berkembang; yaitu pondok pesantren yang didalamnya terdapat sistem pendidikan salaf (weton, sorogan, bandongan) dan sistem klasikal (madrasah) swasta dengan kurikulum $90 \%$ agama dan $10 \%$ umum.

c) Pondok pesantren berkembang; yaitu pondok pesantren seperti semi berkembang, hanya saja sudah lebih bervariasi dalam bidang kurikulumnya, yakni $70 \%$ agama dan $30 \%$ umum. Disamping itu juga diselenggarakan madrasah SKB tiga menteri dengan penambahan diniyah. 
Volume 3 Nomor 2 Edisi Desember 2018

P-ISSN : 2541-3686

d) Pondok pesantren khalaf/modern; yaitu seperti pondok pesantren berkembang, hanya saja sudah lebih lengkap lembaga pendidikan yang ada di dalamya, antara lain diselenggarakan sistem sekolah umum dengan penambahan diniyah (praktek membaca kitab salaf), perguruan tinggi (baik umum, maupun agama), bentuk koperasi dan dilengkapi dengan takhassus (bahasa Arab dan bahasa Inggris).

e) Pondok pesantren Ideal; yaitu sebagaimana bentuk pondok pesantren modern hanya saja lembaga ppendidikan yang ada lebih lengkap, terutama bidang ketrampilan yang meliputi pertanian, teknik, perikanan, perbankankan, dan benar-benar memperhatikan kualitasnya dengan tidak menggeser ciri khusus kepesantrenannya yang masih relevan dengan kebutuhan masyarakat dan perkembangan zaman. Dengan adanya bentuk tersebut diharapkan alumni pondok pesantren benar-benar berpredikat khalifah fil ardhi (Nasir, 2005: 87-88).

Dalam perkembanganya pesantren tidak semata-mata tumbuh atas pola lama yang bersifat tradisional dengan hanya menggunakan pola sorogan dan bandongan. Binti Ma'unah menyatakan, dalam perkembanganya ada tiga sistem pembelajaran yang dikembangkan di pesantren, yaitu; (Ma'unah, 2009: 185).

1) Sistem klassikal

Pola penerapan sistem klassikal adalah dengan pembentukan kelas-kelas dan tingkatan, kluster pembelajaran yang disesuaikan seperti pada sekolah dalam pendidikan formal. Dalam banyak pesantren pola ini sudah banyak di gunakan di sebagai madrasah diniyah atau kegiatan dalam pesantren sebagai pengelompokan pembelajaran yang didasarkan atas kemampuan dan pemahaman selama di pesantren tersebut.

2) Sistem kursus (tahassus)

Pengajaran sistem kursus ini mengarah kepada terbentuknya santri-santri yang mandiri dalam menopang ilmu-ilmu agama yang mereka terima dari Kyai melalui pengajaran sorogan dan bandongan. Sebab pada umumnya para santri diharapkan tidak tergantung kepada pekerjaan di masa mendatang, melainkan harus mampu menciptakan pekerjaan sesuai dengan kemampuan mereka (Ma'unah, 2009: 186).

3) Sistem pelatihan

Pola pelatihan ini dikembangkan untuk menumbuh kembangkan kemampuan praktis seperti pelatihan, pertukangan, perkebunan, perikanan, manajemen koperasi dan kerajinankerajinan yang mendukung tercinptanya kemndirian integratif (Ma'unah, 2009: 186). Dalam banyak pesantren sudah banyak digodog (diusahakan dan di didik pengalaman dan pembelajaranya secara intensif) agar para santrinya mempunyai kemampuan entrepreneur. Hal ini erat kaitanya dengan kemampuan yang lain yang cenderung melahirkan santri yang intelek dan ulama yang mumpuni.

\section{b) Pengembangan kurikulum Madrasah}

Madrasah merupakan salah satu jenis lembaga pendidikan Islam yang di usahakan disamping masjid dan pesantren, sebagai menjadi salah satu lembaga pendidikan tertua di Indonesia, karena sifatnya menganut pemahaman agama yang konservatif tetapi keberadaan pesantren selalu dinamis ditengah pergulatan global, membuat banyak orang tertarik untuk mengkaji pesantren dan madrasah. Dinamisasi tersebut termasuk dengan fleksibilitas madrasah dalam menyerap kepentingan pemerintah melalui penyetaraan program pendidikan madrasah dengan sekolah umum dengan memasukkan muatan disiplin ilmu umum yang sebelumnya tidak diajarkan baik dipesantren maupun madrasah.

Sebenaranya madrasah adalah kata dalam bahasa Arab untuk sekolah, artinya tempat belajar. Istilah madrasah di tanah Arab ditujukan untuk semua sekolah secara umum, namun di Indonesia madrasah ditujukan untuk sekolah-sekolah Islam yang mata pelajaran dasarnya adalah mata pelajaran agama Islam. Lahirnya lembaga ini merupakan kelanjutan dari sistem 


\section{Pengembangan Kurikulum Pesantren, Madrasah dan Sekolah}

\section{Ahmad Arifai}

dunia pesantren yang di dalamnya terdapat unsur-unsur dalam dunia pesantren. Lahirnya lembaga ini merupakan kelanjutan sistem pendidikan pesantren gaya lama, yang dimodifikasi menurut model penyelenggaraan sekolah-sekolah umum dengan sistem kasikal. disamping memberikan pengetahuan agama, diberikan juga pengetahuan umum (Nasir, 2005: 87-88).

Karena pengaruh politik penjajah belanda, sekolah dan madrasah dipandang sebagai dua bentuk lembaga pendidikan yang berbeda, secara dikotomis; sekolah bersifat sekuler dan madrasah bersifat Islami. Hal inilah yang menyebabkan ketika awal kemerdekaan, perkembangan madrasah di Indonesia mengalami konflik yaitu disatu pihak pemerintah ingin menjdikanya sebagai lembaga pendidikan nasional dengan memberikan muatan nonkeagamaan, dan dilain pihak madrasah merasa khawatir akan fungsi pendidikan keagamaanya jika madrasah dimasukkan kedalam jajaran pendidikan nasional (Maksun, 1999: 7).

Dalam upaya memperbaiki dikotomi madrasah sekolah dan meningkatkan kualitas kurikulum pendidikan madrasah. Malik Fadjar selaku menteri agama memantapkan eksistensi madrasah untuk memenuhi tiga tuntutan minimal dalam peningkatan kualitas madrasah, yaitu; 1. Menjadikan madrasah sebagai wahana untuk membina ruh dan praktik hidup keislaman

2. Memperkokoh keberadaan madrasah sehingga sederajat dengan sistem sekolah

3. Madrasah harus mampu merespon tuntutan masa depan guna megantisipasi perkembangan iptek dan era globalisasi.

Kurikulum madrasah secara garis besar, mata pelajaran agama dibagi ke dalam beberapa sub mata pelajaran, yaitu Al-Qur'an-Hadist, Akidah-Akhlak, Fikih, sejarah kebudayaan Islam (SKI), dan ditambah dengan pelajaran Bahasa Arab, sejak MI hingga MA, sehingga porsi mata pelajaran pendidikan agama Islam lebih banyak. Sementara disekolah yang notabene non-madrasah, mata pelajaran pendidikan agama Islam hanya satu, dan porsinya hanya dua jam perminggu. Namun demikian di dalamnya pada dasarnya juga meliputi Al-Qur'an dan Hadist, keimanan (akidah), akhlak, ibadah-syari'ah-mu'amalah (fikih), dan sejarah kebudayaan Islam.

Di madrasah peserta didiknya (putri) menggunakan jilbab, dan peserta didik putera memakai celana panjang, dan banyak di madrasah swasta yang menggunakan peci. Dalam kegiatan pembelajaran madrasah swasta yang terintergrasi dengan pesantren maka diterapkan sistem segregasi, artinya ada pemisahan antara laki-laki dan perempuan, baik itu dalam bentuk kelas yang memang terpisah, dipisah dengan satir meskipun dalam satu kelas, dan ada yang menerapkan untuk siswa pembelajaranya dilaksanakan di pagi hari dan untuk siswi pembelajaranya dilaksanakan di sore hari.

Pengembangan institusional madrasah yang di lakukan oleh kementrian agama sekarang ini sudah dilakukan banyak eksperimen mengenai pengembangan institusional madrasah, salah satunya yang digagas adalah madrasah Model yang di prakarsai oleh kementrian Agama. Madrasah model dimaksudkan untuk membangun percontohan kepada madrasah sekitar yang selama ini merupakan madrasa swasta, sebagai penjamin mutu madrasa swasta di sekitar peningkatan mutu madrasah akan di bentuk cluster-cluster madrasah, yang dalam kelompok tersebut akan dipimpin oleh satu madrasah negerei (MI, MTs, dan MA) model yang akan memimpin pembangunan madrasah disekitarnya (Saleh, 2004: 41).

Untuk menjalankan fungsinya tersebut sebagai model madrasah akan dilengkapi fasilitas-fasilitas pendidikan, seperti perpustakaan, laboratorium IPA, laboratorium bahasa Arab/Inggris, laboratorium computer, bahan-bahan pelajaran seperti teks penunjang, buku pustaka, alat peraga, dan lain sebagainya. Dalam hal pesrsonil akan dipersiapkan guru bergelar master sedikitnya satu orang untuk setiap mata pelajaran, guru kelas, atau guru mata pelajaran yang terlatih di dalam maupun di luar negeri, perpustakaan, teknisi lab, dan staff lainya yang memenuhi syarat (Saleh, 2004: 42). 
Volume 3 Nomor 2 Edisi Desember 2018

P-ISSN : 2541-3686

\section{c) Model Pengembangan Kurikulum Perguruan Tinggi Agama Islam}

Dalam hal pengembangan kurikulum perguruan tinggi agama islam, perubahan IAIN ke UIN adalah wujud dari pengembangan kurikulum yang tidak hanya berorientasikan pada pengetahuan agama Islam saja tetapi juga dalam skala keilmuan yang lebih luas. Kebutuhan masyarakat akan kurikulum pendidikan agama Islam yang lebih progressif dan mampu menjawab kebutuhan masyarakat, membuat lembaga pendidikan tinggi islam harus berbenah diwilayah kurikulum dan pengajaranya. Keberadaan IAIN ketika dilihat belum tampak optimal sebagaimana diharapkan dalam konsep tujuan pendidikan Islam. Dari perspektif sosiologis, masyarakat sebagai stakeholder pendidikan senantiasa dinamis dalam memandang sebuah lembaga pendidikan. IAIN sebagai sebuah institusi sosial dalam masyarakat dituntutuntuk mereformasi diri, agar konsep pendidikan Islam yang universal dan rahmattal lil alamini dapat diaktualisasikan, sebagai respon pemenuhan kebutuhan masyarakat muslim di tanah air.

Bila dilihat dari konsep pendidikan yang universal, implementasi (termasuk kurikulum) IAIN selama ini masih dalam kategori parsial dan dikotomis, dan senantiasa dituntut oleh masyarakat untuk disempurnakan melalui kebijakan reformasi pendidikan tinggi Islam berupa upaya perubahan kelmbagaan IAIN menjadi UIN. Perubahan IAIN menjadi menjadi UIN diharapkan akan meningkatkan kualitas pendidikan yang dijalankan, dari sini pendidikan dan prosesnya senantiasa dituntut untuk up to date dengan perkembangan masyarakat yang dinamis. Mengutip Amin Abdullah paradigma keilmuan kita harus berubah dan berkembang agar keilmuan kita tidak menjadi expired knowledge, atau dippandang sebagai keilmuan yang telah layu atau tidak mampu merefleksikan semangat, tuntutan dan kebutuhan pada zamanya.

Perubahan IAIN menjadi UIN merupakan respon positif terhadap beragam problematika dan dinamika kehidupan masyarakat muslim di Indonesia yang mendambakan suatu perguruan tinggi Islam yang ideal dan yang pernah dipraktekkan pada masa kejayaan Islam pada abad pertengahan. Bebarapa universitas peninggalan abad pertengahan dan terkemuka serta masih eksis hingga saat ini, terutama sering kali merujuk pada kurikulum Universitas Al-Azhar, dan yang menjadi catatan adalah pada awal berdirinya IAIN, kurikulum IAIN berorientasi pada pengembangan kelimuan yang dikembang pada kurikulum Universita al-Azhar, dalam artian kurikulum IAIN ketika awal berdiri merujuk pada kurikulum universitas al-Azhar Mesir. Diantara fakultas di IAIN tiga diantara sama dengan fakultas al-Azhar sejak 1930-an; fakultas Ushuluddin, Syari'ah dan Adab, dan sitem ujian tahunanya juga diambilkan dari Al-Azhar (Meuleman, 2000: 44). Salah satu faktor yang mendukung pengaruh kurikulum model al-Azhar adalah banyaknya lulusan al-Azhar yang memegang kedudukan penting di Departemen Agama dan merancang pendirian IAIN

Keadaan ini sampai pada tahun 1980-an ketika Kementrian agama di bawah pimpinan Munawir Sadzali melakukan pengiriman besar-besar dosen-dosen IAIN ke universitasuniversitas Eropa dan Amrerika, sehingga kemudian orientasi kurikulum IAIN berubah yang dari awlnya berorieantasi ke Universitas Al-Azhar dan timur tenggah berubah pada pengembangan keilmuan yang berorientsi keilmuan barat. Perubahan orientasi IAIN kedlam kuurikulum barat secara nyata tampak ketika Harun Nasution memimpin IAIN Syarif Hidayatullah Jakarta (19731984) yang secara perlahan-lahan berpengaruh kepada IAIN-IAIN yang lain, perubahan tersebut diilhami baik oleh pembangunan nasional yang mensyaratkan dimensi keagamaan yang rasional dan dinamis, maupun oleh tradisi akademis barat. Perubahan ini menekankan bahwa IAIN harus menjadi lembaga pengembangan ilmu agama, bukan pusat doktrin Islam seperti periode sebelumnya (Mueleman, 2000: 48).

Pola dan model kurikulum yang tidak hanya berisikan tentang muatan agama saja tetapi juga merupakan riset dan studi Islam, tidak hanya di utarakan isi tujuan kuurikulum seperti yang telah disebutkan diatas, tetapi juga jenjang dan waktu tempuh studi untuk menyeleisaikan muatan keseluruhan studi yang direncanakan ddalam kurikulum tersebut. 


\section{Pengembangan Kurikulum Pesantren, Madrasah dan Sekolah}

\section{Ahmad Arifai}

Jenjang studi di IAIN adalah S1 (4 Tahun), S2 (2 Tahun), S3 (4 Tahun), sejak dari strata satu studi islam telah dibagi atas berbagai fakultas dan jurusan. Program S2 dan S3 pada program Pascasarjana yang sampai akhir 1980 tidak mempunyai jurusan yang jelas.

Sistem kurikulum yang dipakai di IAIN sebelum tahun 1975 menggunakan sistem kenaikan tingkat. Yaitu yaitu setiap mahasiswa harus lulus semua mata kuliah yang diajarkan pada tingkat yang bersangkutan, jika tidak lulus maka mahasiswa tidak naik tingkat, dan harus mengulang semua mata kuliah pada tahun akademik yang berikutnya. Dan kurikulum 1975 mengubah sistem tingkat menjadi sistem semester, dimana setiap satu semester diadakan ujian untuk mata kuliah yang di ajarkan, dan bagi mereka yang lulus $80 \%$ dari jumlah mata kuliah, maha mahasiswa tersebut dapat mengikuti mata kuliah disemester berikutnya sekalipun yang bersangkutan mengikuti ujian untuk mata kuliah yang belum lulusdan untuk sistem kurikulum yang ada di IAIN jakarta mulai pada tahun 1976 sudah mulai menggunakan sistem SKS (sistem kredit semester), meskipun pada angkatan diatasnya masih menggunakan sistem tingkat (Dirjen Kelembagaan Agama Islam Departemen Agama RI, 1986: 50-51). Dan secara keseluruhan menjelang pertengahan dekade 1980, IAIN tidak lagi menganut sistem naik tingkat seperti yang ada di al-Azhar, tetapi menggunakan SKS yang memberikan peluang bagi mahasiswa untuk lebih cepat menyeleisaikan program studinya (Azra, 2007: 289. Dan program SKS ini tidak langsung jadi seperti sistem pemrograman seperti sekarang tetapi melalui proses pengembangan dan perbaikan, dari mulai paket SKS, sampai pada pemrograman SKS.

Perubahan IAIN menjadi UIN bukan sekedar merubah kurikulum yang merujuk pada konsep pendidikan Islam, tetapi juga sebagai upaya merespon kritik konstruktif terhadap IAIN selama ini hanya hanya berorientasi pada keilmua agama Islam saja. Ke depan UIN diharapkan mampu mengembangkan keduanya, baik keilmuan Agama maupun keilmuan sosial dan teknologi secara integral.

Dalam perubahan Universalitas keilmuan diharapkan nantinya bahwa orang nonmuslim juga mampu bertukar pikiran dalam hal keilmuan dengan umat muslim, setidaknya ketika banyak Universitas Kriten mampu menerima mahasiswa muslim menerima mahasiswa muslim untuk bertukar pikiran tentang keilmuan kenapa universitas Islam tidak, sama halnya ketika banyak sekolah kristen sudah mengalami universalitas keilmuan dan mereka mau menerima siswa muslim kenapa kita tidak, Islam adalah universal, dan keilmuan islam juga harus mampu bermanfaat terhadap peradaban seluruh umat manusia.

\section{Simpulan}

Dalam suatu negara bisa berkembang apabila pendidikan di dalam cukup baik, karana pendidikan merupakan salah satu faktor penentu, dalam negara-negara maju yang pertama kali mereka titik tekankan adalah bagaimana pendidikan itu berkembang, salah satu cara mereka mengembangkan kurikulum, karna pendidikan bisa berkembang apanbila kurikulumnya itu baik karena krikukulum meliputi rencana, tujuan, isi, organisasi, strategi dalam pendidikan.

Peantren \& Madrasah merupakan suatu lembaga pendidikan yang lebih menekankan pada pendidikan agama. Kurikulum PAI di Madrasah memiliki suatu hal yang lebih pokok yang memang diharapkan dan bukan hanya dalam target tujuan PAI tapi juga sebagai pendidikan yang lahir dari agama islam diharapkan dapat berkompetensi jasmani dan rohani, artinya berkompetensi dalam hal sikap, skill, pengetahuan secara afektif, kognitif, psikomotorik sesuai dengan ajaran agama islam dalam aspek jasmani. Dan dengan adanya kurikulum madrasah diharapkan menjadikan anak didik menjadi makhluk yang beriman dan bertaqwa kepada Allah serta senatiasa mau mengamalkan apa yang telah diajarkan di dalam madrasah 
RAUDHAH Proud To Be Professionals qurnal Tarbiyakndamiyah

Volume 3 Nomor 2 Edisi Desember 2018

P-ISSN : 2541-3686

Model pengembangan kurikulum adalah langkah sistematis dalam penyususnan kurikulum. Alternatif prosedur dalam rangka mendesain, menerapkan dan mengevaluasi suatu kurikulum.model pengembangan kurikulum harus dapat menggambarkan suatu proses sistem perencanaan program pembelajaran yang dapat memenuhi berbagai kebutuhan dan standar keberhasilan dalam pendidikan, berdasarkan pada perkembangan teori dan praktek kurikulum. 


\section{Pengembangan Kurikulum Pesantren, Madrasah dan Sekolah}

Ahmad Arifai

\section{DAFTAR PUSTAKA}

Aly, Abdullah, Pendidikan Islam Mulltikulturalisme di Pesantren; Telaah Kurikulm Pondok Pesantren Islam Assalam Surakarta, Yogyakarta; Pustaka Pelajar, 2011.

Aravik, Havis, Pengantar Studi Islam, Palembang: Rafah Press, 2018.

Azra, Azyumardi, Pendidikan Islam Tradisi dan Modernisasi di Tengah Tantangan Millenium III.

Dirjen Kelembagaan Agama Islam Departemen Agama RI Sejarah Institut Agama Islam (Iain) Tahun 1976 Sampai 1980, Jakarta; Dirjen Kelembagaan Agama Islam Departemen Agama RI, 1986.

Ghazali, Bahri, Pesantren Berwawasan Lingkungan, Jakarta; Prasasti, 2002.

Ma'unah, Binti, Tradisi Intelektual Santri, Yogyakarta; TERAS, 2009).

Maksum, Madrasah: Sejarah dan Perkembanganya, Jakarta; Logos Wacana Ilmu, 1999.

Meuleman, Johan Hendrik, "IAIN dipersimpangan jalan", dalam Komaruddin Hidayat dan Hendro Prasetyo (editor), Problem dan Prospek IAIN; Antologi Pendidikan Tinggi Islam, Jakarta; Departemen Agama RI, 2000.

Nasir, Ridwan, Mencari Tipologi Format Pendidikan Ideal; Pondok Pesantren Ditengah Arus Perubahan, Yogyakarta; Pustaka Pelajar,2005.

Saleh, Abd Rachman, Madrasah dan Epndidikan Anak Bangsa; Visi dan Misi, Jakarta; PT Raja Grafindo Pesada, 2004. 